\title{
Volume Table of Raintree (Samanea saman) in Bangladesh by Regression Technique
}

\author{
Sheikh Sirajul Islam, Jonaed Kabir, Abdul Kadar Muhammad Masum \\ Department of Business Administration, International Islamic University Chittagong, Chittagong, Bangladesh \\ Email: \{ssislam, mjk.iiuc, akmmasum\}@yahoo.com
}

Received September 7, 2011; revised October 18, 2011; accepted October 27, 2011

\begin{abstract}
Raintree (Samanea saman) is a multipurpose village tree species grown in abundance at southern and northern regions of Bangladesh. Village people need to know estimation procedure for timber inventory of this useful tree species. Data on diameter at breast height (diameter) and total height (height) of 205 standing sample trees were collected by Spiegel relascope for the purpose. The sample trees with diameter ranging $21 \mathrm{~cm}-91 \mathrm{~cm}$ and height ranging $10 \mathrm{~m}-20 \mathrm{~m}$ were considered for measurement. Volumes $\left(\mathrm{m}^{3}\right)$ of individual trees were computed by Smalian formula. A total of 10 linear models of volume on diameter and volume $(\mathrm{V})$ on diameter $(\mathrm{D})$ and height $(\mathrm{H})$ were examined with the sample trees. A few statistics of F, t, mean square error, multiple correlation coefficient and Furnivall Index was computed and tested for investigation of best fitted models. The two models of $\operatorname{In}(\mathrm{V})=8.3023+2.1746 \operatorname{In}(\mathrm{D})$ and $\operatorname{In}(\mathrm{V})=-9.1864+$ $1.85502 \operatorname{In}(\mathrm{D})+0.8234 \operatorname{In}(\mathrm{H})$ were found to be best fitted models. They have been recommended to estimate volume of large scale standing Raintree trees.
\end{abstract}

Keywords: Volume Table; Raintree; Regression Technique; Profitable

\section{Introduction}

Raintree (Samanea saman) is a large tree mostly grown in southern and northern parts of Bangladesh. It is one of the most important species in Barisal and Khulna districts where it contributes some $19 \%$ of the total volume [1]. It is also planted at higher rate in Patuakhali and Rajshahi. It occupies as best region in respect of number of trees in Chittagong. It is also planted along roadside in many areas in the country. It is an exotic and multipurpose tree species. Village people use its stem and branches as timber and fuel wood respectively. It is also a good fodder tree. Village people get financial benefit out of its plantation.

The local volume tables for important village tree species such as am, jackfruit, jam, mandar, etc were prepared separately by regression technique during Village Forest Inventory in 1981 [2]. The volume tables for teak (Tectona grandis), gamar (Gmelina arborea), and jarul (Lagerstroemia speciosa) were prepared by regression techniques. These species are grown in plantation. Volume table of total 30 indigenous forest species grown naturally were prepared [3]. It is obvious that volume tables for all commercial tree species are available except volume table for Raintree. But volume table of Raintree species is essential for timber inventory works of Forest Department as well as for prospective growers.

In view of above discussions the present study is un- dertaken to establish best relation of volume vs. diameter (one-way volume table) and volume vs diameter and height (two-way volume table) for Raintree planted in both village areas and forest land by multiple regression analysis.

\section{Materials and Method}

A data collection sheet was developed for recording data of Raintree. Since it was not technically feasible to cut standing Raintree trees in the villages, it was decided to measure the standing trees. A team of two persons were engaged for recording measurement of the sample standing trees. One person measured the trees and another person recorded data in the sheet. The total height of a tree in the sample was first measured by Spiegel relascope instrument and was recorded in the sheet [4]. Diameter at breast height of the tree was measured in $\mathrm{cm}$ by a diameter tape. Diameters at every $10 \mathrm{ft}$ height and at height of the top log with 8 inch diameter were measured by the same relascope instrument. Diameter at two ends of branch logs was also measured by relascope. Branches with minimum 8" top diameter were recorded in remarks column of the sheet. The sample trees having 23\% branchy trees were considered. The species was identified easily in the field. In this way data of a sample of 205 trees were recorded in the sheets. Measurement error due to instrumental error as well handling error was re- 
duced by fixing up the instrument properly through actual measurement of a few trees by climbing or felling [5]. A stand table (Table 1) showing an average of 25 trees per diameter class and an average of 35 trees per height class.

All measurement data collected in feet were converted into metric unit through computer. Volume of each log section was calculated by Smalian formula) ( $\mathrm{V}=\mathrm{L} / 2$ $\left(S^{\prime}+S^{\prime \prime}\right), V=$ Volume overbark, $S^{\prime}=$ area of base, $S^{\prime \prime}=$ area of top and $\mathrm{L}=$ Length of log section.) [6]. Volume of each sample tree up to $20 \mathrm{~cm}$ diameter and volume up to the tip height (using conical formula) were calculated through computer. Thus three variables namely, diameter $(\mathrm{cm})$, height $(\mathrm{m})$ and volume $\left(\mathrm{m}^{3}\right)$ of a tree were generated. The volume regressions were fitted for the sample trees. The following regression equations [7] were considered for selection of best fitted models:

1) $V=a+b D$

2) $V=a+b D^{2}$

3) $\ln (\mathrm{V})=\mathrm{a}+\mathrm{b} \ln (\mathrm{D})$

4) $\mathrm{V}=\mathrm{a}+\mathrm{bD}+\mathrm{c} \mathrm{D}^{2}$

5) $\mathrm{V}=\mathrm{a}+\mathrm{bD} \mathrm{D}^{2} \mathrm{H}$

6) $\ln (\mathrm{V})=\mathrm{a}+\mathrm{bln}(\mathrm{D})+\mathrm{cln}(\mathrm{H})$

7) $\mathrm{V}=\mathrm{a}+\mathrm{bD}^{2}+\mathrm{cH}+\mathrm{dD}^{2} \mathrm{H}$

8) $\mathrm{V}=\mathrm{a}+\mathrm{bD}^{2}+\mathrm{CDH}+\mathrm{dD}^{2} \mathrm{H}$

9) $\mathrm{V} / \mathrm{D}^{2} \mathrm{H}=\mathrm{a}+\mathrm{b} \mathrm{D}^{2} \mathrm{H}+\mathrm{C} / \mathrm{H}+\mathrm{d} / \mathrm{D}^{2}$

10) $\mathrm{V} / \mathrm{D}^{2} \mathrm{H}=\mathrm{a}+b \mathrm{D}^{2} \mathrm{H}+\mathrm{C} / \mathrm{H}+\mathrm{d} / \mathrm{D}$

where, $\mathrm{V}=$ Volume $\left(\mathrm{m}^{3}\right)$ overbark, $\mathrm{D}=$ diameter $(\mathrm{cm})$ at breast height, $\mathrm{H}=$ total height $(\mathrm{m}), \mathrm{a}=$ regression constant and b,c,d = regression coefficients.

The regression equation through the selection tests such as F-test, t-test, coefficient of determination $\left(\mathrm{R}^{2}\right)$, mean square error (MSE) and Furnivall Index (FI) were examined. Furnivall Index is estimated through multiplying square root of the residual mean square of a volume regression by geometric mean of the weight of the dependent variable [8]. It was first developed by Furtively in 1961 for weighted models [9]. The best regression equations were selected and particularly, the best models of volume-diameter (One-Way Volume Table) and volume-diameter-height (Two way volume table) may be used to compute volume of standing raintree trees as per requirement.

\section{Result and Discussion}

A total of 10 regression equations mentioned earlier was fitted with 205 sample trees [10]. A few statistics such as $\mathrm{F}, \mathrm{t}, \mathrm{MSE}, \mathrm{R}^{2}$ and FI were computed and compared for each of 10 regression equations. On the basis of $\mathrm{F} \& \mathrm{t}$ significance, small MSE \& FI and more $\mathrm{R}^{2}$ the two models were selected and shown in Table 2.

The amount of variation explained by the two models is $86 \%$ and $90 \%$ respectively. The variation explained is quite a good amount, Fl which contains MSE indicates small figure for both the models, $\mathrm{F}$ and t show highly significant. So, the two models have been selected as suitable ones. The volume-diameter model is, however, only considered for the purpose of calculating volume of a Raintree tree [11]. This is the model by which volume

Table 1. Stand table of 205 sample trees.

\begin{tabular}{|c|c|c|c|c|c|c|c|}
\hline \multirow{2}{*}{ Diameter (cm) } & \multicolumn{6}{|c|}{ Height (m) } & \multirow[b]{2}{*}{ Total } \\
\hline & 10 & 12 & 14 & 16 & 18 & 20 & \\
\hline 21 & 23 & 8 & 8 & - & - & - & 29 \\
\hline 31 & 24 & 28 & 15 & 1 & - & - & 68 \\
\hline 41 & 10 & 22 & 12 & 5 & - & - & 49 \\
\hline 51 & 7 & 14 & 10 & 7 & 2 & 1 & 41 \\
\hline 61 & 2 & 4 & - & 5 & 1 & 1 & 13 \\
\hline 71 & - & - & 1 & 1 & 1 & - & 3 \\
\hline 81 & - & - & - & 1 & - & - & 1 \\
\hline 91 & - & - & - & - & - & 1 & 1 \\
\hline Total & 56 & 76 & 46 & 20 & 4 & 3 & 205 \\
\hline
\end{tabular}

Table 2. The statistics of best selected models.

\begin{tabular}{ccccccc}
\hline Model & MSE & FI & $\mathrm{R}^{2}$ & $\mathrm{~F}$ & $\mathrm{t}_{1}$ & $\mathrm{t}_{2}$ \\
\hline $1 \operatorname{lr}(\mathrm{V})=-8.3013+2.1746 \ln (\mathrm{D})$ & 0.07 & 0.21 & 0.86 & 1273.79 & 35.69 & - \\
$2 \ln (\mathrm{V})=-9.1864+1.8502 \ln (\mathrm{D})+0.8234 \ln (\mathrm{H})$ & 0.05 & 0.18 & 0.90 & 916.98 & 29.09 & 8.24 \\
\hline
\end{tabular}


of a large number of standing Raintree trees can be estimated quickly through measurement of diameter at breast height only. The volume table prepared on the basis of this volume-diameter model is called one way volume table and shown in Appendix I. Another model needs measurement of both diameter at breast height and total height of standing trees [12]. Although it takes time and sometimes difficult to measure the total height of the standing trees correctly, this model provides better volume estimates than another model. The volume table prepared on the basis of this volume-diameter-height model is called two way volume tables and shown in Appendix II. Actual volume of same sample felled trees measured for verification during data collection was calculated. This calculated volume was compared with the estimated volume taken from both one-way volume table and two-way volume table. It is found that the estimated volume is almost same as the actual volume of Raintree trees. Therefore, the two volume tables may be used to compute volume of standing Raintree trees.

\section{Acknowledgements}

The authors would like to express their appreciation to the Editor and an anonymous referee for constructive and valuable comments that considerably improved the quality and the appearance of the manuscript.

\section{REFERENCES}

[1] Anon, "Project Findings and Recommendation," Village Forest Inventory, UNDP/FAO Project BGD/78/020, Terminal Report, 1982.

[2] S. A. Aleem, "Project Report on Tree Volume Tariff and
Bamboo Weight Tariff for Village Forest Inventory of Bangladesh,” UNDP/FAO Project BGD/78/020, 1981.

[3] S. S. Islam, "Volume Tables for Some Indigenous Forest Species in Bangladesh,” Bulletin No. 3, Forest Inventory Series, BFRI, Chittagong, 1984.

[4] M. R. K. Jerram and R. Bourne, "Elementary forest mensuration,” Thomas Murby and Company, London, 1949.

[5] S. S. Islam, N. A. Reza, M. Hasnin, M. A. S. Khan and M. R. Islam, "Volume Tables of Young Keora (Sonneratia Apetala) Trees for the Western Coastal Belt of Bangladesh,” Bulletin No. 1, Plantation Trial Unit Series, BFRI, Chittagong, 1992.

[6] A. C. Smith, "Flora Vitiensis Nova,” Pacific Tropical Botanical Garden, Vol. 3, 1985.

[7] R. R. Thaman and W. A. Whistler, "Review of Uses and Status of Trees and Forests in Land-Use Systems in Samoa, Tonga, Kiribati and Tuvalu with Recommendations for Future Action,” South Africa, 1996.

[8] A. W. Whistler, "The Ethnobotany of Tonga," Bishop Museum Bulletin in Botany, Vol. 2, 1991, pp. 1-155.

[9] M. A. Latif, M. N. Islam and J. H. Chowdhury, "Tree Volume Tables for Four Species Grown in Plantations in Bangladesh,” Bulletin No. 2, Inventory Division, BFRI, Chittagong, 1984, pp. 92-121.

[10] S. S. Islam, “Commercial Volume Table for Teak (Tectona Grandis Linn.f.) in Bangladesh by Regression Technique,” Bano Biggyan Patrika, Vol. 17, No. 1-2, 1988, pp. 53-67.

[11] R. C. Barneby and J. W. Grimes, "Silk Tree, Guanacaste, Monkey'S Earring, a Generic System for the Synandrous Mimosaceae of the Americas. Part I. Abarema, Albizia, and Allies," Memoirs of the New York Botanical Garden, , Vol. 74, No. 1, 1996, pp. 1-292.

[12] CAB International, "Forestry Compendium,” CAB International Wallingford, 2003. 


\section{Appendix I. One Way Volume Table $\left(\mathrm{m}^{3}\right)$}

Regression Equation: $\operatorname{Ln}(\mathrm{V})=-8.3013+2.1746 \operatorname{Ln}(\mathrm{D})$.

Species: Raintree (Samania saman)

Total volume over bark $=$ Stem volume over bark up to $10 \mathrm{~cm}$ top diameter + Branch wood volume over bark up to $10 \mathrm{~cm}$ top diameter.

\begin{tabular}{|c|c|}
\hline Diameter (cm) & Volume $\left(\mathrm{m}^{3}\right)$ \\
\hline 20 & 0.1675 \\
\hline 22 & 0.2061 \\
\hline 24 & 0.2490 \\
\hline 26 & 0.2963 \\
\hline 28 & 0.3482 \\
\hline 30 & 0.4045 \\
\hline 32 & 0.4655 \\
\hline 34 & 0.5311 \\
\hline 36 & 0.6013 \\
\hline 38 & 0.6764 \\
\hline 40 & 0.7562 \\
\hline 42 & 0.8408 \\
\hline 44 & 0.9303 \\
\hline 46 & 1.0248 \\
\hline 48 & 1.1241 \\
\hline 50 & 1.2285 \\
\hline 52 & 1.3379 \\
\hline 54 & 1.4523 \\
\hline 56 & 1.5718 \\
\hline 58 & 1.6965 \\
\hline 60 & 1.8262 \\
\hline 62 & 1.9612 \\
\hline 64 & 2.1014 \\
\hline 66 & 2.2468 \\
\hline 68 & 2.3975 \\
\hline 70 & 2.5535 \\
\hline 72 & 2.7149 \\
\hline 74 & 2.8815 \\
\hline 76 & 3.0536 \\
\hline 78 & 3.2310 \\
\hline 80 & 3.4139 \\
\hline 82 & 3.6022 \\
\hline 84 & 3.7960 \\
\hline 86 & 3.9953 \\
\hline 88 & 4.2001 \\
\hline 90 & 4.4105 \\
\hline 92 & 4.6264 \\
\hline 94 & 4.8479 \\
\hline 96 & 5.0750 \\
\hline 98 & 5.3078 \\
\hline 100 & 5.5461 \\
\hline
\end{tabular}




\section{Appendix II. Two Way Volume Table $\left(\mathrm{m}^{3}\right)$}

Regression Equation: $\operatorname{Ln}(\mathrm{V})=-9.1864+1.8502 \operatorname{Ln}(\mathrm{D})+0.8234 \operatorname{Ln}(\mathrm{H})$

Species: Raintree (Samania saman)

Total volume over bark = Stem volume over bark up to $10 \mathrm{~cm}$ top diameter + Branch wood volume over bark up to $10 \mathrm{~cm}$ top diameter.

\begin{tabular}{|c|c|c|c|c|c|c|c|}
\hline & & \multicolumn{6}{|c|}{ Height (m) } \\
\hline & & 10 & 12 & 14 & 16 & 18 & 20 \\
\hline \multirow[t]{41}{*}{ Diameter (cm) } & 20 & 0.1742 & 0.2024 & 0.2298 & 0.2565 & 0.2826 & 0.3082 \\
\hline & 22 & 0.2078 & 0.2414 & 0.2741 & 0.3059 & 0.3371 & 0.3676 \\
\hline & 24 & 0.2440 & 0.2836 & 0.3219 & 0.3594 & 0.3960 & 0.4318 \\
\hline & 26 & 0.2830 & 0.3288 & 0.3733 & 0.4167 & 0.4592 & 0.5008 \\
\hline & 28 & 0.3246 & 0.3772 & 0.4282 & 0.4780 & 0.5266 & 0.5744 \\
\hline & 30 & 0.3688 & 0.4285 & 0.4865 & 0.5430 & 0.5984 & 0.6526 \\
\hline & 32 & 0.4156 & 0.4829 & 0.5482 & 0.6119 & 0.6742 & 0.7353 \\
\hline & 34 & 0.4649 & 0.5402 & 0.6133 & 0.6846 & 0.7543 & 0.8226 \\
\hline & 36 & 0.5167 & 0.6004 & 0.6817 & 0.7609 & 0.8384 & 0.9144 \\
\hline & 38 & 0.5711 & 0.6636 & 0.7534 & 0.8410 & 0.9266 & 1.0106 \\
\hline & 40 & 0.6280 & 0.7297 & 0.8284 & 0.9247 & 1.0189 & 1.1112 \\
\hline & 42 & 0.6873 & 0.7986 & 0.9067 & 1.0121 & 1.1151 & 1.2162 \\
\hline & 44 & 0.7491 & 0.8704 & 0.9882 & 1.1030 & 1.2154 & 1.3255 \\
\hline & 46 & 0.8133 & 0.9450 & 1.0729 & 1.1976 & 1.3195 & 1.4391 \\
\hline & 48 & 0.8799 & 1.0224 & 1.1608 & 1.2957 & 1.4276 & 1.5570 \\
\hline & 50 & 0.9489 & 1.1026 & 1.2519 & 1.3973 & 1.5397 & 1.6792 \\
\hline & 52 & 1.0203 & 1.1856 & 1.3461 & 1.5025 & 1.6555 & 1.8056 \\
\hline & 54 & 1.0941 & 1.2714 & 1.4434 & 1.6112 & 1.7753 & 1.9362 \\
\hline & 56 & 1.1703 & 1.3599 & 1.5439 & 1.7233 & 1.8988 & 2.0709 \\
\hline & 58 & 1.2488 & 1.4511 & 1.6475 & 1.8389 & 2.0262 & 2.2098 \\
\hline & 60 & 1.3296 & 1.5450 & 1.7541 & 1.9580 & 2.1574 & 2.3529 \\
\hline & 62 & 1.4128 & 1.6416 & 1.8638 & 2.0804 & 2.2923 & 2.5000 \\
\hline & 64 & 1.4983 & 1.7410 & 1.9766 & 2.2063 & 2.4310 & 2.6513 \\
\hline & 66 & 1.5861 & 1.8430 & 2.0924 & 2.3356 & 2.5734 & 2.8066 \\
\hline & 68 & 1.6761 & 1.9476 & 2.2112 & 2.4682 & 2.7195 & 2.9660 \\
\hline & 70 & 1.7685 & 2.0549 & 2.3330 & 2.6042 & 2.8694 & 3.1294 \\
\hline & 72 & 1.8631 & 2.1649 & 2.4579 & 2.7435 & 3.0229 & 3.2969 \\
\hline & 74 & 1.9600 & 2.2774 & 2.5857 & 2.8862 & 3.1801 & 3.4683 \\
\hline & 76 & 2.0591 & 2.3926 & 2.7164 & 3.0322 & 3.3409 & 3.6437 \\
\hline & 78 & 2.1605 & 2.5104 & 2.8502 & 3.1814 & 3.5054 & 3.8231 \\
\hline & 80 & 2.2641 & 2.6308 & 2.9869 & 3.3340 & 3.6735 & 4.0065 \\
\hline & 82 & 2.3699 & 2.7538 & 3.1265 & 3.4899 & 3.8453 & 4.1938 \\
\hline & 84 & 2.4780 & 2.8794 & 3.2690 & 3.6490 & 4.0206 & 4.3850 \\
\hline & 86 & 2.5882 & 3.0075 & 3.4145 & 3.8113 & 4.1995 & 4.5801 \\
\hline & 88 & 2.7007 & 3.1382 & 3.5629 & 3.9770 & 4.3820 & 4.7791 \\
\hline & 90 & 2.8154 & 3.2714 & 3.7141 & 4.1458 & 4.5680 & 4.9820 \\
\hline & 92 & 2.9322 & 3.4072 & 3.8683 & 4.3179 & 4.7576 & 5.1888 \\
\hline & 94 & 3.0513 & 3.5455 & 4.0253 & 4.4931 & 4.9507 & 5.3994 \\
\hline & 96 & 3.1725 & 3.6863 & 4.1852 & 4.6716 & 5.1474 & 5.6139 \\
\hline & 98 & 3.2958 & 3.8297 & 4.3480 & 4.8533 & 5.3476 & 5.8322 \\
\hline & 100 & 3.4213 & 3.9755 & 4.5136 & 5.0381 & 5.5512 & 6.0543 \\
\hline
\end{tabular}

